\title{
Synthesis of Thermal Phase Separating Reactive Polymers and Their Applications in Immobilized Enzymes*
}

\author{
Feng LiU, Guoliang TAO, and Renxi ZHUO \\ Department of Chemistry, Wuhan University, \\ Wuhan, Hubei 430072, P.R. China
}

(Received July 20, 1992)

\begin{abstract}
This paper describes the synthesis of active ester copolymers from $N$ isopropylacrylamide (NIP) with $\mathrm{N}$-acryloxysuccinimide (NAS), aminolysis of active esters, and determination of their average molecular weights. As a model, thermolysin was attached to the polymer to form soluble-insoluble immobilized enzymes capable of being centrifuged above their $T_{\mathrm{c}}$, because poly $\left(N\right.$-isopropylacylamide) (poly(NIP)) has a lower critical solution temperature $\left(T_{\mathrm{c}}\right)$ of about $31-33^{\circ} \mathrm{C}$. The effects of immobilization of enzymes have been studied including the amount of active ester, time, $\mathrm{pH}$, temperature, and ratio of polymer to enzyme. The tests of thermal stability and repeated precipitation and separation showed that the use of $T_{\mathrm{c}}$ as the technique of separation is possible.
\end{abstract}

KEY WORDS Polymerization / Phase Separating Reactive Polymers / Poly ( $N$-isopropylacrylamide) / Immobilization of Enzyme / Thermolysin /

The immobilization of enzymes using insoluble carriers has been widely studied. ${ }^{1,2}$ However, because of the solid substrate and/or product in carriers, effective enzyme reaction does not occur in its insoluble form. In order to overcome the problems of insoluble enzyme reaction systems, the preparation of solubleinsoluble enzymes has been attempted. This type of immobilized enzyme shows a soluble state during catalytic reaction but an insoluble form after the reaction. Several papers have reported such immobilized enzymes by changing the $\mathrm{pH}$ or salt concentration of reaction medium after the reaction to bring about this reversible procedure. ${ }^{3-8}$

It is well-known that aqueous solutions of $\operatorname{poly}(N$-isopropylacrylamide) (poly(NIP)) exhibit a lower critical solution temperature $\left(T_{\mathrm{c}}\right)$, at which demixing occurs, of about $31-33^{\circ} \mathrm{C}$ throughout a wide concentration range (up to $c a$. 5\%). ${ }^{9,10}$ This thermally reversible characteristic has been successfully exploited in an immunoassay and protein separation, in which many of the advantages of both homogeneous and heterogeneous methods are obtained. ${ }^{11,12}$ So we are encouraged to extend this technique to immobilize enzymes.

This paper describes the synthesis of thermally-reversible reactive water-soluble copolymers obtained by copolymerizing $N$ isopropylacrylamide (NIP) with $\mathrm{N}$-acryloxy-
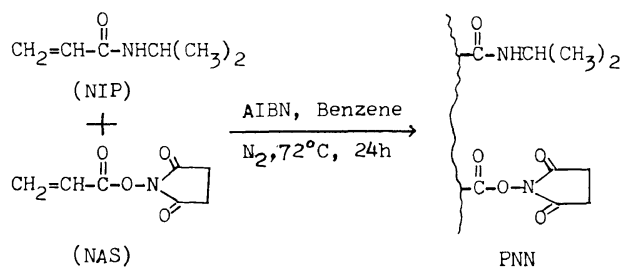

Synthesis of PNN

Scheme 1.

\footnotetext{
* The project supported by National Natural Science Fundation of China.
} 


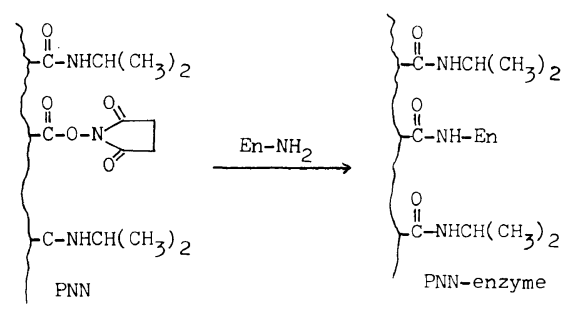

Immobilization of enzyme

Scheme 2.

succinimide (NAS) (Scheme 1), assays of active ester and determination of number average molecular weights. As a model thermolysin was attached to the polymers to form water-soluble immobilized enzymes (Scheme 2). The immobilization conditions were studied and the stability of the immobilized thermolysin was also investigated.

\section{EXPERIMENTAL}

\section{Materials}

Thermolysin and casein were purchased from Sigma (St. Louis, Mo.). $N$-Acryloxysuccinimide (NAS) ${ }^{9}$ and acryloylchloride ${ }^{13}$ were synthesized according to reported methods. $2,2^{\prime}$-Azobisisobutyronitrile (AIBN) $\left(\mathrm{mp} 103^{\circ} \mathrm{C}\right)$, trichloro acetic acid (TCA), mercaptoethanol (bp $157^{\circ} \mathrm{C}$ ), isopropylamine (bp $34^{\circ} \mathrm{C}$ ), ethylene diamine tetraacetic acid (EDTA) (mp $250^{\circ} \mathrm{C}$ (dec.)), and tris(hydroxymethyl)aminoethane (Tris) were all purchased and used without further purification.

\section{Instruments}

IR spectra were recorded on a Nicolet 170SX spectrophotometer. UV spectra were run with a Shimadzu UV-240 spectrophotometer. Viscosity was determined by a Ubbelodhe viscosimeter.

\section{Methods}

Synthesis of N-Isopropylacrylamide (NIP). NIP was synthesized with acryloylchloride $(27.3 \mathrm{~g}, 0.3 \mathrm{~mol})$ and isopropylamide $(35.4 \mathrm{~g}$,
$0.6 \mathrm{~mol})$ in ethylacetate at $0^{\circ} \mathrm{C}$ with stirring for $4 \mathrm{~h}$. After the reaction the precipitate was filtered, the filtrate was concentrated and then was applied to a Vacuum liquid Chromatography (VLC). ${ }^{14}$ All collected fractions were put together and the solvent was removed. The residue was dried and then recrystallized twice with a mixed solvent of benzene and hexane. The colorless needle crystals were separated by filtration. Yield: $24.4 \mathrm{~g}(72 \%)$ mp 62-63 ${ }^{\circ} \mathrm{C}$ (lit. ${ }^{9} \mathrm{mp} 62-63^{\circ} \mathrm{C}$ ); IR (KBr) $\mathrm{cm}^{-1}$ : 3300, 3090, 2990, 2890, 1660, 1620, 1550, 1250, and 920. NMR: $7.70-8.30(\mathrm{~s}$, $1 \mathrm{H}), 6.20-6.40(\mathrm{~d}, 2 \mathrm{H}), 5.30-5.70(\mathrm{t}, 1 \mathrm{H})$, $3.70-4.40$ (s, 1H). Elemental analysis, Calcd: C, $63.68 \%$; H, 9.80\%; N, 12.38\%. Found: C, $63.66 \% ; \mathrm{H}, 9.85 \%$; N, $12.30 \%$.

Synthesis of Poly( $N$-isopropylacrylamideco-N-acryloxysuccinimide) (PNN). The copolymerization of $N$-acryloxysuccinimide $(9.9 \mathrm{~g}$, $87.5 \mathrm{mmol}), N$-acryloxysuccinimide $(0.93 \mathrm{~g}, 5.5$ $\mathrm{mmol}$ ), was carried out in the presence of AIBN $(30 \mathrm{mg})$ in $200 \mathrm{ml}$ of benzene at $72^{\circ} \mathrm{C}$ for $24 \mathrm{~h}$. Ethyl ether $(400 \mathrm{ml})$ was added at the end of reaction to precipitate the polymr. After removal of the supernatant, the polymer was dissolved in $200 \mathrm{ml}$ of acetone, and then the acetone solution was pured into vigorously stirred ethyl ether $(800 \mathrm{ml})$. The precipitated fluffy polymer was washed on the funnel four times with $100 \mathrm{ml}$ aliquots of ethyl ether. This procedure was repeated twice. Then the polymer was dried in a vaccum desiccator in 1.0 Torr for $48 \mathrm{~h}$ at ambient temperature to constant weight: $10.2 \mathrm{~g}(94 \%)$. IR (KBr) $\mathrm{cm}^{-1}$; 3080, 2990, 1750, 1660, 1375, 1215, and 1075 .

\section{Determination of the Molecular Weight of $P N N$}

The number average molecular weights of aminolyzed PNN samples were calculated from their intrinsic viscosities, ${ }^{10}$ determined as described by Flory. ${ }^{15}$ Aminolysis of PNN was accomplished by treatment of the polymer $(50 \mathrm{mg}$ ) with $2 \mathrm{ml}$ of isopropylamine for $24 \mathrm{~h}$ 
at room temperature. Then the solvent was distilled and the residue was dissolved in acetone and precipitated by ethyl ether. This procedure was repeated three times.

\section{Assay for the Active Ester Content of PNN}

PNN $(50 \mathrm{mg}$, about $53 \mu \mathrm{mol}$ of active ester groups, dried under vacuum at 1 Torr and $25^{\circ} \mathrm{C}$ for $48 \mathrm{~h}$ ) was dissolved and made up to volume in distilled water in a $5 \mathrm{ml}$ volumetric flask. A $50 \mu \mathrm{l}$ of this solution was added into a $5 \mathrm{ml}$ quartz cuvette containing $3000 \mu \mathrm{l}$ of Tris- $\mathrm{HCl}$ buffer $(0.1 \mathrm{M}, \mathrm{pH} 7.5), 50 \mu \mathrm{l}$ of $1 \mathrm{M}$ isopropylamine aqueous solution and $10 \mu \mathrm{l}$ of $1 \mathrm{M}$ solution of mercaptoethanol. The rate of the appearance of $N$-hydroxysuccinimide was followed spectrophotometrically at $259 \mathrm{~nm}$ at $25^{\circ} \mathrm{C} .{ }^{16}$ After the reaction was completed and increase of absorbance level off, the active ester concentration was calculated.

\section{Immobilization of Thermolysin}

PNN $(500 \mathrm{mg})$ was placed in a beaker containing a small stirring bar, and $10 \mathrm{ml}$ of $0.01 \mathrm{M} \mathrm{Ca}(\mathrm{OAc})_{2}$ buffer $\mathrm{pH} 7.3$ and $10 \mathrm{ml}$ of $0.2 \mathrm{mg} \mathrm{ml}^{-1}$ thermolysin in $0.01 \mathrm{M} \mathrm{Ca}(\mathrm{OAc})_{2}$ solution were added. The polymer was dissolved within $0.5 \mathrm{~h}$ at about $10^{\circ} \mathrm{C}$ by stirring. The polymer solution was stirred magnetically for $24 \mathrm{~h}$ at $17^{\circ} \mathrm{C}$ to ensure complete immobilization of the enzyme. After the reaction, the solution was removed to a centrifuge tube and centrifuged for $30 \mathrm{~min}$ at $10000 \mathrm{rpm}$ in a $35^{\circ} \mathrm{C}$ air bath. The supernatant was removed. The precipitate was then dissolved in $20 \mathrm{ml}$ Tris$\mathrm{HCl}$ buffer $\mathrm{pH} 7.5$ and stored at $4^{\circ} \mathrm{C}$.

\section{Assay for Enzyme Activity}

1) Assay for Activity of Free Enzyme. ${ }^{17}$ $0.1 \mathrm{ml}$ enzyme solution $(1 \mathrm{mg} / 10 \mathrm{ml})$ and $1.9 \mathrm{ml}$ of $0.01 \mathrm{M}$ Tris- $\mathrm{HCl}$ buffer $\mathrm{pH} 8.0$ were pipetted into a test tube. $1 \mathrm{ml}$ casein $(2 \% \mathrm{pH}$ 8.0) was also pipetted into the tube. The solutions were mixed well and the reaction was carried out for $10 \mathrm{~min}$ at $35^{\circ} \mathrm{C}$. At the end of the reaction, $2 \mathrm{ml}$ of TCA were added.
After being shaken, the tube was kept in a $35^{\circ} \mathrm{C}$ water bath for $30 \mathrm{~min}$. The precipitate was filtered off through filter paper, and absorbance of the filtrate was measured at $280 \mathrm{~nm}$. The activity unit was corrected by a standard curve and represented by $[\mathrm{PU}]^{\text {ca. } 35^{\circ} \mathrm{C}, 280 \mathrm{~nm} .{ }^{18}}$ The specific activity of the thermolysin is calculated to be 157 .

2) Assay for Activity of Immobilized Enzyme. $0.2 \mathrm{ml}$ of immobilized enzyme solution and $1.8 \mathrm{ml}$ of $0.01 \mathrm{M}$ Tris- $\mathrm{HCl}$ buffer $\mathrm{pH} 8.0$ were pipetted into a test tube, and $1 \mathrm{ml}$ casein $(2 \%, \mathrm{pH} 8.0)$ was pipetted as well. The other steps were repeated as described above.

\section{Measurement for the Activity of Immobilized \\ Thermolysin after Repeated Use}

$0.2 \mathrm{ml}$ immobilized thermolysin solution was added to $2.8 \mathrm{ml}$ Tri- $\mathrm{HCl}$ buffer solution (pH 8.0). After being stirred at $35^{\circ} \mathrm{C}$ for about $10 \mathrm{~min}$, the mixture was centrifuged at $35^{\circ} \mathrm{C}$ for $30 \mathrm{~min}$. The supernatant was removed, and the precipitate dissolved again with $2.0 \mathrm{ml}$ Tris- $\mathrm{HCl}$ buffer. When the immobilized thermolysin was completely dissolved, its activity was assayed according to the method above, and the cycles of this process was counted as the number of repeated use. In this way we measured the activity of immobilized thermolysin for repeated use from one to five times.

\section{RESULTS AND DISCUSSION}

\section{Preparation of Copolymers and Their Char- acteristics}

PNN was prepared by the free-radical polymerization of $N$-isopropylacrylamide (NIP) and $N$-acryloxysuccinimide (NAS) in benzene solution, using thermal initiation with AIBN (Scheme 1). This system was used in order to provide suitable molecular weight polymers, which dissolved quickly and generated an aqueous solution of suitable viscosities and could also be precipitated effectively above $T_{\mathrm{c}}$. A buffer solution containing the 
Table I. Preparation of NIP/NAS copolymers and their characteristics ${ }^{a, b}$

\begin{tabular}{|c|c|c|c|c|c|c|}
\hline \multirow{2}{*}{ Polymer } & \multicolumn{3}{|c|}{ Reaction conditions } & \multirow{2}{*}{$\frac{\text { Yield }}{\%}$} & \multirow{2}{*}{$\bar{M}_{n} \times 10$} & \multirow{2}{*}{$\begin{array}{l}\text { Content of active } \\
\text { ester }\left(\times 10^{2}\right)\end{array}$} \\
\hline & $R \times 10^{2}$ & $T /{ }^{\circ} \mathrm{C}$ & $t / \mathrm{h}$ & & & \\
\hline PNN-I & 1.54 & 72 & 24 & 95 & 1.85 & 1.43 \\
\hline PNN-2 & 3.42 & 72 & 24 & 96 & 1.75 & 3.15 \\
\hline PNN-3 & 6.82 & 72 & 24 & 94 & 1.78 & 5.78 \\
\hline PNN-4 & 12.3 & 72 & 24 & 94 & 1.72 & 11.1 \\
\hline PNN-5 & 22.4 & 72 & 24 & 93 & 1.60 & 19.7 \\
\hline
\end{tabular}

a Ratio of moles of active ester to moles of NIP.

b Ratio of moles of measured active ester to moles of NIP.

polymer up to $5 \%$ by weight formed steadily. Conversion of monomers to copolymers was consistently high. They appeared to be indefinitely stable at room temperature in a desiccator under dry air; the active ester groups, however, hydrolysed on exposure of PNN to undried air, but this hydrolysis was slow. The polymer was assayed for active ester by allowing it to react with an isopropylamine solution and measuring the absorbance due to the anion of $N$-hydroxysuccinimide $\left(E_{259}\right.$ $8600 \mathrm{M}^{-1} \mathrm{~cm}^{-1}$ ). Usually, the content of active ester groups in a sample of polymer was $85-95 \%$ as that expected on the basis of the composition of monomers. Several polymers differing in active ester content were used in this experiment.

The number average molecular weights of the polymers were estimated by converting them to $\operatorname{poly}(N$-isopropylacrylamide by reacting with excess of isopropylamine. The viscosities of their aqueous solutions were measured by a Ubbelodhe Viscosimeter. The difference between $N$-hydroxysuccinimide and isopropylamine was also considered in the calculation of $M_{n}$ by viscosity. All experimental data are listed in Table I.

\section{Precipitation and Separation}

It has been known that poly ( $N$-isopropylacrylamide) and PNN-protein have a $T_{\mathrm{c}}$ of about $31-33^{\circ} \mathrm{C}$ throughout a wide concentration range. We utilized this demixing behavior of poly(NIP) at or above the $T_{\mathrm{c}}$ as the separation technique in our experiment above $33^{\circ} \mathrm{C}$, phase separation occurred; however, precipitates were difficult to filter and collect; because their viscous flocculate hindered the performance of ultrafiltration. But we found that polymers could be centrifuged almost completely from solution for $30 \mathrm{~min}$ at $10000 \mathrm{rpm}$ in a $35^{\circ} \mathrm{C}$ air bath.

\section{Immobilization of Enzyme}

Thermolysin was coupled to the active ester copolymers via formation of amide bond by nucleophilic substitution of succinimidyl groups in the polymers (Scheme 2). After coupling, we did not separate the enzymeimmobilized polymer from the unreacted polymer, because when compared to that in unseparated system, the activity of the immobilized enzyme dropped after being separated from the unreacted polymer by the method of Hoffman et al. ${ }^{19}$ So the unreacted polymer has no influence on the activity of immobilized enzyme.

Table II shows that PNN-3 is a suitable carrier to immobilize an enzyme, because the relative activity of the immobilized enzyme with PNN-3 as carrier is highest, and the remaining activity is also perfectly good. In order to find optimum immobilization conditions, we immobilized thermolysin at different $\mathrm{pH}$, temperatures, times, and ratios of polymer to enzyme. From Table III we can see 
Table II. Characterization of immobilized thermolysin

\begin{tabular}{cccc}
\hline & $\begin{array}{c}\text { Remaining } \\
\text { activity }^{\mathbf{a}}\end{array}$ & & $\begin{array}{c}\text { Relative } \\
\text { activity }^{\mathbf{b}}\end{array}$ \\
\cline { 2 - 2 } Polymer & $\%$ & $\%$ \\
\hline PNN-1 & 15 & & 85 \\
PNN-2 & 21 & & 89 \\
PNN-3 & 30 & & 92 \\
PNN-4 & 32 & 90 \\
PNN-5 & 35 & 87 \\
\hline
\end{tabular}

Note: Immobilization was carried out under the same conditions: $\mathrm{pH}, 7.2 ; T, 17^{\circ} \mathrm{C} ; t, 30 \mathrm{~h}$; ratio of PNN to enzyme (w/w), 250.

a Remaining activity $(\%)=$ activity of immobilized enzyme/activity of free enzyme in solution $\times 100 \%$.

b Relative activity ( $\%)=$ activity of immobilized enzyme/ (activity of free enzyme in solution-activity of free enzyme in filtration solution) $\times 100 \%$.

Table III. Immobilization conditions and remaining activity of $\mathrm{PNN}-3$-thermolysin

\begin{tabular}{rrrrrrrr}
\hline $\mathrm{pH}^{\mathrm{a}}$ & $\mathrm{RA}^{\mathrm{b}}$ & $T /{ }^{\circ} \mathrm{C}^{\mathrm{c}}$ & $\mathrm{RA}^{\mathrm{b}}$ & $\mathrm{R}^{\mathrm{d}}$ & $\mathrm{RA}^{\mathrm{d}}$ & $\mathrm{IT}^{\mathrm{e}}$ & $\mathrm{RA}^{\mathrm{b}}$ \\
\hline 6.2 & 15.6 & 0 & 25.0 & 500 & 22.0 & 1.0 & 8.0 \\
7.2 & 29.9 & 17 & 29.7 & 250 & 19.8 & 8.0 & 17.8 \\
7.8 & 29.7 & 23 & 28.5 & 125 & 18.2 & 20.0 & 24.3 \\
8.1 & 22.4 & 30 & 7.9 & 42 & 16.7 & 30.0 & 29.7 \\
\hline
\end{tabular}

a $T, 17^{\circ} \mathrm{C} ; t, 30 \mathrm{~h}$.

b Remaining activity (\%).

c $\mathrm{pH} 7.2 ; t, 30 \mathrm{~h}$.

d Ratio of PNN-3 to thermolysin (w/w): $\mathrm{pH} 7.2 ; T$, $17^{\circ} \mathrm{C} ; t, 30 \mathrm{~h}$.

e Immobilization time (h): $\mathrm{pH} 7.2 ; \mathrm{T}, 17^{\circ} \mathrm{C}$; ratio of PNN-3 to thermolysin (w/w) was $250: 1$ in a, c, and e.

that the optimum conditions are: $\mathrm{pH} 7.2$, temperature $17^{\circ} \mathrm{C}$, ratio 500 , time $30 \mathrm{~h}$.

\section{Effect of Repeated Usage}

The durability of immobilized enzymes is very important to application, because they are subject to repeated use on residual activity (highest activity among tested immobilized enzymes was $100 \%$ ) of casein hydrolysis by immobilized thermolysin. From Figure 1 it can be seen that the activity of immobilized thermolysin does not decrease very much with

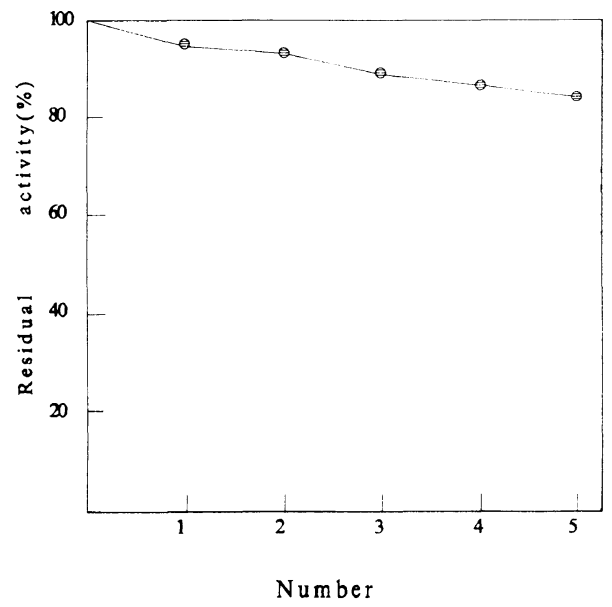

Figure 1. Effects of the repeated use on the residual activity of casein hydrolysis at $\mathrm{pH}$ 8.0.

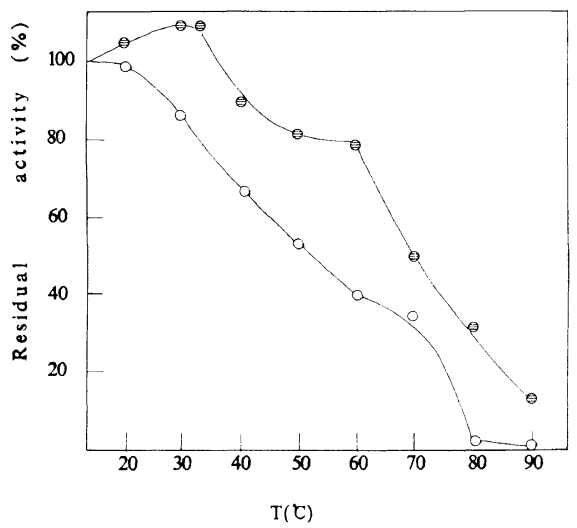

Figure 2. Effects of heat treatment at given temperatures and $\mathrm{pH} 8.0$ for $1 \mathrm{~h}$ on the residual activity of casein hydrolysis at $\mathrm{pH} 8.0$ and $35^{\circ} \mathrm{C} .(\bigcirc)$, native enzyme; $(\theta)$, PNN-enzyme.

increase of cycles and remains over $80 \%$ after five times.

\section{Effect of Heat Treatment}

We know that the thermal stability of immobilized enzymes is a very important characteristic in usage. This is also the basis for the use of $T_{\mathrm{c}}$ as the separation technique in our lab. From Figure 2 it can be seen that the immobilized thermolysin is more stable than free native thermolysin at all tempera- 


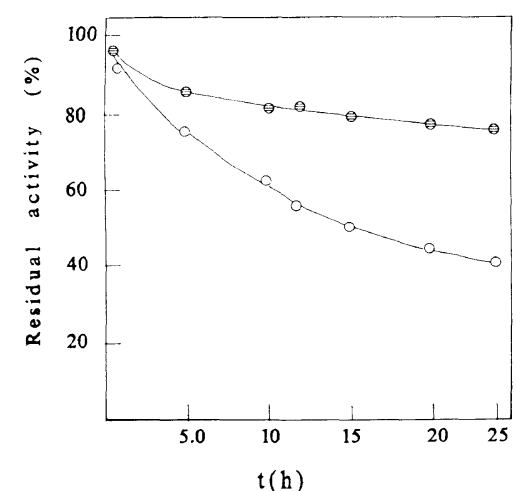

Figure 3. Effects of storage in buffer at $\mathrm{pH} 8.0$ and $50^{\circ} \mathrm{C}$ on the residual activity of casein hydrolysis at $\mathrm{pH}$ 8.0 and $35^{\circ} \mathrm{C}$. ( $\left.\bigcirc\right)$, native enzyme; $(\Theta)$, PNN-enzyme.

tures. When kept for $1 \mathrm{~h}$ within $40^{\circ} \mathrm{C}$, the activity of thermolysin did not decrease. So we believe that the technique used in our lab is available.

\section{Storage Stability}

The immobilized thermolysin and free native thermolysin were stored at $50^{\circ} \mathrm{C}$ in $0.01 \mathrm{M}$ Tris- $\mathrm{HCl}$ buffer (pH 7.2), and after a certain interval, the activities of immobilized thermolysin and free native enzyme were assayed. From Figure 3 we can see that the immobilized thermolysin was more stable than the free native enzyme.

\section{Effect of Temperature}

In Figure 4 the immobilized and free native thermolysin hydrolysed the casein at different temperatures. It can be seen that the optimum temperature of immobilized thermolysin shifted to $5^{\circ} \mathrm{C}$ higher compared with that of the free native enzyme.

\section{Optimum $p H$}

The effects of $\mathrm{pH}$ on the rate of hydrolysis of casein by native thermolysin and immobilized thermolysin were compared. As shown in Figure 5, the optimum $\mathrm{pH}$ and $\mathrm{pH}$-activity profile of immobilized thermolysin shifted in parallel $c a .0 .7 \mathrm{pH}$ units to the alkaline side

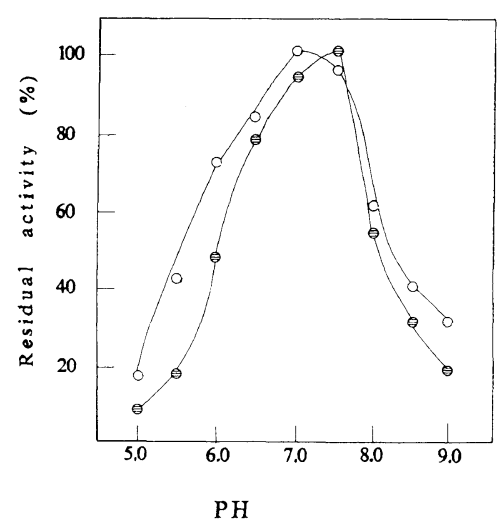

Figure 4. Effects of $\mathrm{pH}$ on the residual activity of casein hydrolysis at $\mathrm{pH} 8.0$ and $35^{\circ} \mathrm{C}$, treatment at given $\mathrm{pH}$ and $25^{\circ} \mathrm{C}$ for $30 \mathrm{~min}$. ( $\left.\mathrm{O}\right)$, native enzyme; ( $\left.⿴\right)$ ), PNN-enzyme.

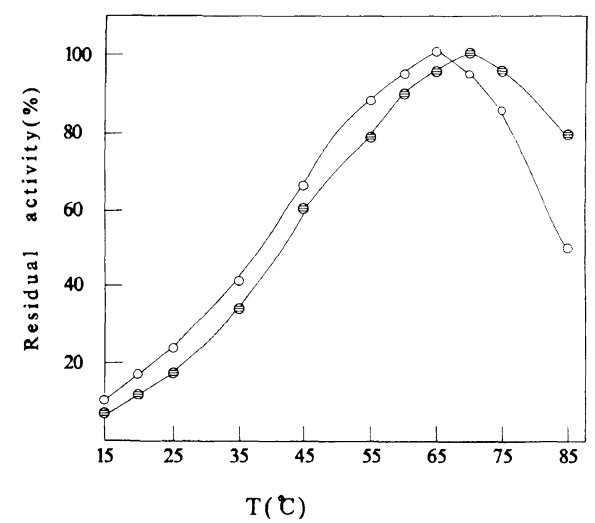

Figure 5. Activity was assayed at different temperatures and $\mathrm{pH} 8.0$ on the hydrolysis of casein. (O), native enzyme; $(\theta)$, PNN-enzyme.

compared with those of native thermolysin.

\section{Effect of EDTA}

EDTA is a strong inhibitor of thermolysin. ${ }^{20}$ So we assayed the activity of thermolysin and native enzyme at different concentrations of EDTA. From Figure 6 we can see that immobilized thermolysin is more stable than native enzyme at all concentrations of EDTA.

\section{CONCLUSIONS}

The results obtained in our study show that 


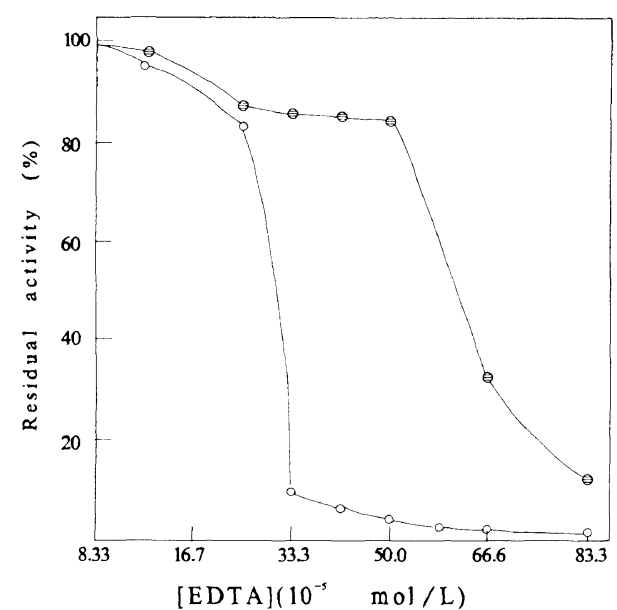

Figure 6. Effects of different concentration of EDTA on the residual activity of casein hydrolysis at $\mathrm{pH} 8.0$ and $35^{\circ} \mathrm{C}$, EDTA $=8.33 \times 10^{-5} \mathrm{M}$. ( $\left.\bigcirc\right)$, native enzyme; (

the polymer we synthesized in our lab can be used for the immobilization of an enzyme, and because of its characteristics of $T_{\mathrm{c}}$, it can also be precipitated by raising the temperature and separated. In this procedure, the activity of the immobilized enzyme does not decrease. The major advantage of this method is that it avoids using strong acid or a solution with a high concentration of salt as the means of precipitating the polymer, or else, the enzyme would be destroyed. For instance, a $\mathrm{pH}-$ sensitive enzyme such as thermolysin would be damaged by strong acid. The thermal stability of most enzymes after being immobilized, can be greatly increased so that most of them withstand heat treatment around $35^{\circ} \mathrm{C}$ without loss of activity. The method used in our lab can bring about enzyme reaction in its soluble form, and separation in its insoluble form. We are now studying possible applica- tions of this technique to enzyme-catalytic reaction.

\section{REFERENCES}

1. C. G. Gebelein and C. E. Carraher, "Bioactive Polymeric Systems," Plenum Press, New York and London, 1985, p 249.

2. K. Mosbach, "Methods in Enzymology," Vol. 44, Academic Press, New York, N.Y., 1976.

3. M. Charls, R. W. Couglin, and F. X. Hasselberger, Biotechnol. Bioeng., 16, 1553 (1974).

4. E. V. Leemputten and M. Horisber, Biotechnol. Bioeng., 18, 587 (1976).

5. K. Okamura, K. Ikura, M. Yoshikawa, R. Sakaki, and H. Chiba, Agric. Biol. Chem., 48, 2435 (1984).

6. A. L. Margolin, V. A. Izumrudov, V. K. Svedas, and A. B. Zeain, Biotechnol. Bioeng., 24, 237 (1982).

7. M. Taniguchi, M. Kobayashi, and M. Fujii, Biotechnol. Bioeng., 34, 1029 (1989).

8. A. L. Nguyen and J. H. T. Luong, Biotechnol. Bioeng., 34, 1186 (1989).

9. M. Heskins and J. E. Guillet, J. Macromol. Sci. Chem., A2(8), 1441 (1968).

10. P. Molyneux, "Water-Soluble Synthetic Polymers," Vol. 1, CRC Press, Boca Raton, FL, 1985.

11. N. Monji and A. S. Hoffman, Allied Biochem. Bioeng., 14, 107 (1987).

12. A. S. Hoffman, Polym. Prepr., Am. Chem. Soc., Div. Polym. Chem., 31, 220 (1990).

13. G. H. Stempel, J. Am. Chem. Soc., 72, 2299 (1950).

14. N. M. Targett, J. P. Kilcoyne, and B. Green, J. Org. Chem., 44 (26) 4962 (1979).

15. P. J. Flory, "Principles of Polymer Chemistry," Cornell University Press, Itacha, N.Y., 1953, pp $308-314$.

16. O. Adalsteinsson, A. Lamotte, R. F. Baddour, C. K. Colton, A. Pollak, and G. M. Whiteside, J. Mol. Catal., 6, 199 (1953).

17. H. Matsubara, in "Methods in Enzymology, G. E. Perlmann and L. Lorand, Ed., Vol. XIX, Academic Press, New York and London, 1970, p 642.

18. Y. Ohta, Y. Ogura, and A. Wada, J. Biol. Chem., 241, 5919 (1966).

19. J. P. Chen, H. J. Yang, and A. S. Hoffman, Biomaterials, 625 (1990).

20. S. Endo, J. Ferment. Technol., 40, 346 (1962). 